\title{
DOI https://doi.org/10.32841/2409-1154.2020.44.21
}

Андрійченко Ю. В., доктор фбілологічних наук, профбесор кафедри романської фбілологї Інституту фбілології Київського національного університету ілені Тараса Шевченка

\section{ОСОБЛИВОСТІ ВИНИКНЕННЯ ГЕНДЕРНИХ ДОСЛІДЖЕНЬ У ЛІНГВІСТИЦІ НА СУЧАСНОМУ ЕТАПІ}

\begin{abstract}
Анотація. Аналіз стану гендерних студій у сучасній лінгвістиці виразно демонструє, що лише незначну кількість робіт присвячено кроскультурним дослідженням. Практично немає фундаментальних комплексних досліджень ыз метою систематизації проблеми, пов'язаної з особливостями прояву гендерних змін в іспанській мові. Процеси конструювання гендеру зазвичай вивчаються 3 огляду на номінативні ресурси мови; роль семіотичних засобів і глибинних (структурних) механізмів мови та дискурсу враховується меншою мірою. На сучасному етапі гендер є важливим, але не єдиним параметром, який бере участь у конструюванні соціальної ідентичності мовця. Під гендером ми розуміємо сукупність соціально зумовлених і соціально значущих аспектів поведінки чоловіків і жінок, у т. ч. і мовної, які конструюються і виражаються в межах культури певного суспільства. Картина світу це система образів, знань, уявлень про предмети і явища навколишнього світу того або іншого народу; на формування цієї системи впливає значною мірою процес когніції, оскільки в когнітивній антропології вважається, що у кожного народу система сприйняття і мислення є різною, і також на формування картини світу впливають мова, традиції, природа, виховання та інші соціальні фактори, що стосуються народу. В іспаномовній картині світу стереотипізовані уявлення про чоловіка як про голову своєї родини і про жінку як про покірну домогосподарку зазнали суттєвих змін, що відображено в появі великої кількості лексем у формі жіночого роду, які називають професії, що раніше вважалися суто чоловічими. Взаємопов'язані категорії роду, статі та гендеру є експонентами лінгвістичного знання (рід) і позамовного знання (стать, гендер), що пояснює їхню неоднорідну репрезентацію і неоднакову роль у мові та комунікації.

Статтю присвячено аналізу нової дослідницької парадигми, яка спирається на принцип антропоцентризму у вивченні мовних явищ. Важливого значення набувають індивідуальні характеристики мовної особистості. До однієї з найважливіших належить гендер, котрий визначає соціальну, культурну та когнітивну орієнтацію індивіда у світі. Гендерні дослідження в мовознавстві з'явилися нещодавно, у 70-80-ті pp. минулого століття. Сьогодні можемо можна стверджувати про становлення гендерної лінгвістики.
\end{abstract}

Ключові слова: гендер, гендерні стереотипи, комунікація, лінгвістичний сексизм, мовні стереотипи.

Мета статті - проаналізувати сучасну методологію гендерних досліджень у сучасній іспанській мові.

Завдання дослідження вбачаємо в аналізі становлення сучасної гендерної лінгвістики в контексті загального розвитку науки про мову, в розгляді ступеня й особливості впливу категорії «гендер» на мовну діяльність індивіда; також вважаємо за потрібне дослідити методологію та різні підходи до інтерпретації результатів гендерних досліджень у лінгвістиці й обгрунтувати принципи сучасного підходу до цієї проблеми.

Предметом дослідження $є$ гендерно маркована лексика: гендерні стереотипи, реалізовані в мові, гендерно марковані метафоричні одиниці 3 гендерним компонентом як основні функціональні одиниці гендерної мовної картини світу.

Об'єктом дослідження цієі статі обрані мовні явища в сучасній іспанській мові, в яких простежується асиметрія за гендерними ознаками.

Актуальність статі визначається належністю іiї теми до одного із перспективних напрямів андроорієнтованого дослідження мови лінгвістичної гендерології і та 3 необхідністю теоретичного обгрунтування певної низки проблем, які, незважаючи на інтенсивний розвиток гендерних студій, недостатньо висвітлені.

Виклад основного матеріалу. Гендерні дослідження з'явилися 3 метою встановлення розбіжностей між біологічними чинниками, що роблять різними чоловіків і жінок, і гендерними чинниками, які $€$ продуктом культури. Базовим постулатом слугує твердження, що вся соціальна організація людства збудована за гендерними розбіжностями, в основі яких є певна іерархія, де маскулінне превалює над фемінним. Зміни в гендерних проявах залежать від часу і типу культур, в яких вони розвиваються. У кожному суспільстві існують генералізовані моделі, як жіночі, так і чоловічі, зі сталими варіантами за соціальними класами, расою, релігією, національністю і сексуальними уподобаннями. Хоча слід зазначити, що гендерні дослідження мають за мету не лише пояснення відносин, які встановилися між обома статями, а і їхне трансформування.

Сьогодні фокус аналізу досліджень статі зазнав суттевих змін: вже не йдеться про те, яким чином біологічна стать впливає на використання мови і комунікативну поведінку. Важливим $€$ те, якими засобами оперує мова для конструювання гендера, в яких комунікативних ситуаціях він відбувається, як мовні та позамовні фактори впливають на цей процес. У центрі всіх теоретичних постулатів, пов'язаних із вивченням ключової лінгвістичної проблеми - мова в людині та людина в мові - знаходиться культура, маркована національними особливостями. У зв'язку із сучасним розумінням гендеру як компоненту колективної та індивідуальної свідомості, що був створений мовними засобами, існує необхідність усвідомлення цього феномену з позиції когнітивної науки. 
Вивчення гендерних відносин набуває особливої актуальності у зв'язку з істотними змінами в соціальному житті людей різних країн. Гендерні дослідження в лінгвістиці виникли задовго до ХХ ст. та сягають своїм корінням античності - часів, коли виникла символіко-семантична концепція категорії роду (genus), що розглядалася у зв'язку з наявністю людей і осіб різної статі. Аристотель протиставляв чоловічий рід, який асоціюється 3 дією й енергією, жіночому - пасивному [1]. Великі німецькі лінгвісти кінця XVIII - початку XIX ст. В. Гумбольдт, I. Гердер вважали, що відмінності між статями в мові пов'язані з відмінностями статей у природі [2, с. 225-250].

Сучасні феміністські течії розкритикували деякі теоретичні аспекти гендерної теорії, оскільки вони охоплюють як питання, що стосуються жінок, так і ті, які стосуються чоловіків, що, на їхню думку, веде до нейтральної позиції дослідження. Дослідники ж маскулінності навпаки стверджують, що саме загальногендерні дослідження надали їм поштовх для подальших студій. Галузі дослідження, у яких працюють психологи, лінгвісти, антропологи і соціологи, пов'язані з темами сексуальності, мачизму та ін. Дослідження маскулінності усе ще знаходяться на початковому етапі і мають на меті визначення конфлікту, в якому опиняються чоловіки за зміни чоловічої особистості. У своїй роботі А. Гарсія Месегер надає пояснення того, що через не повне визначення фемінності, зміну традиційних гендерних ролей і відносин у парі маскулінна ідентифікація змушує чоловіків розпочати перегляд своїх цінностей, стереотипів і підштовхує до зміни соціальної поведінки [3].

Гендерні дослідження можна поділити на три етапи. Перший охоплював усе XIX та перші роки XX ст. Тогочасні теорії визначають, що біологічні відмінності між статями повністю виправдовують існування соціальної нерівності. Так само аргументується, що роль жінки, яку вона повинна виконувати в суспільстві - це вторинна роль спостерігача. Тому галузь, де вона себе може проявити - це виключно домашнє господарство.

Другий етап досліджень розпочався на Заході після закінчення Другої світової війни. Дослідники відкинули біологічні аспекти та сконцентрували свою увагу на соціальних чинниках. Феміністські теорії того періоду зупинилися на процесі соціалізації, який був відповідальний за статеві розбіжності. Гендер починає розглядатися вже як соціальна конструкція.

Останній третій етап розпочався в 70-х рр. минулого століття, коли гендер став предметом дослідження науковців. Академічний англосаксонський фемінізм надав поштовх вживанню цього концепту, наполягаючи на постулаті про те, що гендерні розбіжності збудовані соціально, а не біологічно.

У зарубіжній лінгвістиці 70-90рp. ХХ ст. гендерні дослідження проводилися у межах чотирьох основних напрямів: теорії дефіцитності жіночої мови, домінантної теорії, диферентної теорії та теорії перформативності [4].

У перших двох напрямах, представниками якого $€$ П. Фішман, Р. Лакофф, Б. Торн, Н. Хенлі, К. Вест, Д. Зіммерман, як базове використовується поняття домінуюча мужність, внаслідок чого жінки розглядаються як загноблена соціальна група, а мовні відмінності інтерпретуються в термінах владна «чоловіча мова» та «безвладна жіноча мова» [4].

Представники диферентної теорії, серед яких були Д. Таннен та ін., пояснюють гендерні відмінності існуванням комунікативно протилежних субкультур: жіночої та чоловічої, що сягають корінням у глибоке дитинство, де створюються та роз- виваються різні культурні світи - світ хлопчиків і дівчаток. Ця модель слугує прикладом того, як теоретична орієнтація дослідників щодо гендеру впливає на його визначення і варіативність мови. Їхнє дослідження також грунтується на припущеннях статевої біологічної теорії: модель передбачає, що конфлікт самців має орієнтацію на правосуддя. За цією теорією під час конфлікту чоловік підтримує універсальну думку i використовує мову, щоб викликати повагу до себе. Чоловіки використовують логіку та раціональність у спробі вирішити конфлікт [5, с. 145-238].

Iз 80-х рр. минулого століття поняття гендеру розпочали використовувати у різних соціальних дисциплінах, оскільки це виявилося корисним для пояснення, яким чином біологічні відмінності перетворюються на економічні, соціальні та політичні між чоловіками і жінками, розмістивши детермінантів статевої нерівності на символічній, культурній, історичній площині. У цьому сенсі сприйняття гендеру як категорії для аналізу мало значення важливого епістемологічного переривання за останні декади у науці, оскільки ввело визнання соціальної нерівності, яке доти знаходилося виключно в економічній площині як за класовою теорією, так і за теорією соціальної стратифікації.

3 погляду антропологічної науки гендер визначається як культурна та історична інтерпретація, яку кожне суспільство виробляє щодо статевої диференціації. Ця інтерпретація дає місце комплексу соціальних репрезентацій, практикам, дискурсам, нормам, цінностям і відносинам, іншими словами - системі стать / гендер, що надає сигнали моделям поведінки осіб відповідно до їхньої статі. Внаслідок цього гендер структурує як сприйняття, так і конкретну і символічну організацію всього соціального життя. Найважливішою дискусійною проблемою гендерних досліджень у сучасному мовознавстві залишається питання про співвідношення біологічних, психологічних, соціальних і культурних чинників, які впливають на гендерні відмінності у мові та мовленні.

Біодетерміністська теорія заснована на значному впливі відмінностей у гормональних системах і міжпівкулевій асиметрії мозку у чоловіків і жінок на їхню мовну поведінку, внаслідок чого розрізняють когнітивні, емоційні та фізичні параметри статевої диференціації. Соціодетерміністські теорії, до яких належать феміністська та маскулінна лінгвістика, виявляють домінуючий вплив суспільства і культури, тобто динамічних і рухливих соціальних чинників на формування гендерних відмінностей, що підтверджується аналізом комунікативної поведінки чоловіків і жінок у різних культурах у процесі соціалізації. Не заперечуючи існування біологічних, психологічних і соціальних відмінностей у представників соціуму, гендерні дослідження демонструють, що важливою є не стільки констатація відмінностей, скільки їхня соціокультурна оцінка та інтерпретація, що лежить в основі системи гендерного домінування, прийнятого в суспільстві.

Гендерні дослідження охоплюють дві великі галузі:

1) Мова: прояви сексизму, тобто гноблення за статевою ознакою (за аналогією з расизмом) у системі мови та їі функціонуванні.

2) Мовлення: зумовлені статтю особливості мовної поведінки чоловіків і жінок.

Дослідження у першій галузі зародилися в межах критичної лінгвістики, яка має на меті аналіз як неявних, так і прозорих структурних відносин домінування, дискримінації, влади 
і контролю, виражених у мові. Ціла низка лінгвістів поділяє думку Ю. Габермаса 3 приводу того, що мова є також засобом домінування і соціальної сили [6]. Вона слугує для законодавчого закріплення відносин організованою владою. Наскільки законодавчо закріплені (легітимні) відносини влади, настільки мова $є$ ідеологізованою [7].

Дослідження в іншій галузі пов'язані із соціолінгвістикою, яка вивчає вплив окремих соціальних і соціально-демографічних ознак (віку, статі, рівня освіти) на функціональне використання мови у процесі мовної комунікації. Недоліком сучасної соціолінгвістики деякі вчені вважають той факт, що вона не відповідає аргументовано на запитання, чи існують відмінності в мові, а якщо існують, то які вони між двома основними групами людей - чоловіками та жінками [7].

Інтерес до гендерного аспекту комунікації в останні десятиріччя зростає. У переліку робіт відображається специфіка взаємодії соціальних процесів і гендерних відносин [7; 8]. Дослідження механізмів гендерної комунікації, iї структури та ролі в сучасному суспільстві дозволяє зробити висновок: чим вищий рівень соціального розвитку суспільства, тим менше виявляється диференціювання за статевою належністю в мові, яка їі обслуговує [9, с. 125-127].

Статева належність накладає відбиток на усю сутність людини, вона визначає не тільки соціальну статеву роль, яку виконує людина, але і їі свідому модель світу, іiі взаємини зі світом, мотиви дій і вчинків, стиль поведінки. Людина, змінюючи своє мовлення, може змінювати своє мислення і звільнитися від гендерних стереотипів, що вкоренилися у суспільстві. В аналізі проблеми мовної репрезентації гендеру основним, на нашу думку, є розуміння гендеру як безперервного процесу продукування суспільством відмінностей у чоловічих і жіночих ролях, ментальних і емоційних характеристиках у мовній поведінці. Гендерні норми і ролі не мають універсального змісту і тому варіюються у різних суспільствах.

А.В. Кириліна в своїх дослідженнях системно описала мову з огляду на гендерний фактор і систематизувала методологічні підходи до дослідження цієї проблеми в лінгвістиці $[8 ; 9]$. Якщо розглядати сучасний стан гендерних досліджень, то існують три фундаментальні підходи. Перший iз них охоплює виключно соціальне трактування мови представників обох статей і має за мету дослідити ті мовні розбіжності в сучасному суспільстві, які можна пояснити соціальними змінами. Чоловіча або жіноча мова визначається як певна функціональна похідна від основної мови та використовується у тих випадках, коли комуніканти перебувають на різних ступенях соціальної ієрархії. Другий підхід має назву соціопсихолінгвістичного і науково редукує чоловічу і жіночу мови до особливостей мовної поведінки обох статей.

Прихильники третього напряму наполягають на когнітивному аспекті розбіжностей у мовній поведінці чоловіків і жінок. Важливу роль відіграють не лише визначення кількості розбіжностей і оперування його показниками, але і створення цілісних лінгвістичних моделей когнітивного підгрунтя мовних категорій [10]. У сучасній лінгвістиці усі три підходи вважаються важливими. А.В. Кириліна відокремлює шість основних напрямів, які можуть бути диференційовані як концептуально, так і з погляду методології та характеру матеріалу, що досліджується:

1) Соціолінгвістичні гендерні дослідження.

2) Феміністська лінгвістика.
3) Дослідження мовної поведінки обох статей.

4) Дослідження маскулінності.

5) Психолінгвістичні дослідження. До цього напряму належать дослідження когнітивних особливостей і відмінностей між чоловіками і жінками та їхні прояви в мовленні у межах біодетерміністського підходу.

6) Кроскультурні, лінгвокультурологічні дослідження, які включають у себе гіпотезу гендерних субкультур [8].

Однак А.В. Кириліна вважає, що вищезазначена класифікація $€$ умовною: усі шість напрямів мають багато спільного між собою, оскільки вони характеризуються спільною проблематикою й об'єктом дослідження [7]. Зазвичай об'єктом дослідження стає взаємозв'язок мови і статі, тобто питання про те, яким чином стать виражається у мові. Основною метою цих студій $є$ опис і пояснення появи статі в мові, оцінкам чоловіка і жінки, і в яких саме семантичних галузях вони найчастіше вживаються.

Перспективами дослідження вважаємо продовження вивчення гендерної ідеології, яка є системою вірувань, за допомогою яких люди пояснюють і виправдовують свою поведінку. Вона також інформує і спрямовує інтерпретацію та оцінку поведінки інших, встановлюючи норми, що регулюють участь у гендерному порядку, і за допомогою яких пояснюють і виправдовують свою участь. Мова є ключовим інструментом, за яким поширюється гендерна ідеологія, що розрізняється за природою чоловічого і жіночого.

\section{Jimepamypa:}

1. Аристотель. История животных / перевод В.П. Карпова, под ред. Б.А. Старостина. Москва : РГГУ, 1996. 528 с.

2. Гумбольдт В. Избранные труды по языкознанию. Москва : Прогресс, 2000. С. 225-250.

3. Meseguer García Álvaro. Es sexista la lengua española? Madrid : Ed. Paidós, 1994. 254 p.

4. Лакофф Р. Язык и место женщины. Введение в гендерные исследования, часть II : Хрестоматия, под ред. С.В. Жеребкина. Харьков : ХЦГИ, 2001. 798 с.

5. Таннен Д. Ты меня не понимаешь! Почему женщины и мужчины не понимают друг друга. Москва : РГГУ, 1995. С. 144-238.

6. Habermas J. Knowledge and Human Interests. London : Heinemann, 1990. $363 \mathrm{p}$

7. Горошко Е.И. Языковое сознание: гендерная парадигма. Текст. Харьков : ИД «ИНЖЭК», 2003. 440 c.

8. Кирилина А.В. Гендерные стереотипы в языке. Словарь гендерных терминов / под ред. А.А. Денисовой. Москва : Информация XXI век, 2002. $256 \mathrm{c}$.

9. Кириллова А.В. Гендерные различия в коммуникации. Тула : Знание, язык, культура, 2007. С. 125-127.

10. Molina García B. Morfosintaxis funcional española. Madrid : Ed. SURCO, 2006. 353 p.

Andriichenko Yu. Peculiarities of gender research in linguistics at the actual moment

Summary. The article has been devoted to the analysis of the state of gender studies in modern linguistics and clearly shows that only a small number of works are devoted to cross-cultural studies. There is virtually no fundamental comprehensive research to systematize the problem of genderspecific changes in Spanish. Gender processes are usually studied in terms of the language's nominative resources; the role of semiotic means and profound (structural) mechanisms of language and discourse is less taken into account. 
At the present, gender is an important but it isn't the only parameter that is involved in the construction of the social identity of the speaker. By gender we mean a set of socially conditioned and socially significant aspects of the behavior of men and women, including language, which are constructed and expressed within the culture of a particular society. The picture of the world is a system of images, knowledge, ideas about objects and phenomena of the world around the world; the formation of this system is influenced, to a large extent, by the process of cognition, since in cognitive anthropology it is believed that in each nation the system of perception and thinking is different, and also the formation of the picture of the world is influenced by language, traditions, nature, education and other social factors, relevant to this people. In the Spanish-speaking world, stereotypical perceptions of a man as head of his family and a woman as a humble housewife have undergone significant changes, which are reflected in the emergence of a large number of feminine-style tokens, called professions that were previously considered purely masculine. The interrelated categories of gender, biological sex are exponents of linguistic knowledge (gender) and linguistic knowledge (biological sex), which explains their heterogeneous representation and unequal role in language and communication.

The article is devoted to the analysis of a new research paradigm based on the principle of anthropocentrism in the study of linguistic phenomena. Individual characteristics of the linguistic personality are of great importance. One of the most important is gender, which determines the social, cultural and cognitive orientation of an individual in the world. Gender studies in linguistics have emerged recently, in the 1970s and 1980s. Today we can say about the development of gender linguistics.

Key words: gender, gender stereotypes, spanish world paintings, communication, language stereotypes. 